\title{
THE FORECASTING OF FINANCIAL INCLUSION IN EAST JAVA THROUGH ISLAMIC MICROFINANCE INSTITUTION: AN AUTOREGRES- SIVE INTEGRATED MOVING AVERAGE APPROACH
}

\author{
Muhammad Anif Afandi*1 \\ Indanazulfa Qurrota A'yun²
}

\footnotetext{
${ }^{1}$ Student in Master of Islamic Economics and Finance, Islamic Middle East Studies, University of Indonesia, Indonesia

${ }^{2}$ Studentin Master of Economics, Faculty of Economics and Business, Gadjah Mada University, Indonesia
}

\begin{abstract}
Financial inclusion is an effort intended to eliminate price and non-price barriers toward public access to formal financial institutions. The aim of that is income equalization of the societies affecting increasing economic growth, poverty alleviation, and financial system stability. East Java is one of the provinces in Indonesia with the most number of Islamic Rural Banks (BPRS). This study wants to find out how the role of BPRS in realizing the acceleration of Islamic financial inclusion in East Java. Then, this research is conducted in the period January 2014 - May 2018 in which data sourced from the Islamic Banking Statistics (SPS), Financial Services Authority (FSA). An Autoregressive Integrated Moving Average (ARIMA) is applied as research method to predict the level of Islamic financial inclusion in East Java through BPRS by using three from four financial inclusion indicators released by Bank Indonesia in 2014 namely access with number of BPRS as its proxy, usage with amount of third party funds and amount of financing as its proxies, and quality with total assets and Non- Performing Financing (NPF) as its proxies. The results show that based on forecasting values until December 2020, the number of BPRS predicted will decrease with the last number as many as 27 banks, DPK will increase with the last number $1,680,558.79$ million Rupiah, the amount of financing will increase with the last number as many as 1,822,810.80 million Rupiah, asset will increase with the last number 2,299,250.44 million Rupiah, and NPF will increase with the last number 12.48 percent.
\end{abstract}

Keywords: Financial Inclusion, Islamic Rural Banks, ARIMA, East Java JEL: N25, G21

\section{ARTICLE INFO}

Received: October $21^{\text {st }}, 2018$ Revised: November $2^{\text {nd }}, 2018$ Accepted: December $11^{\text {st }}, 2018$ Online: December $25^{\text {th }}, 2018$

\author{
*Correspondence: \\ Muhammad Anif Afandi \\ E-mail: \\ afandianif@gmail.com
}

To cite this document: Afandi, M. A. \& A'yun, I. Q.,(2018). The Forecasting of Financial Inclusion in East Java Through Islamic Microfinance Institution: An Autoregressive Integrated Moving Average Approach. JDE (Journal of Developing Economies), 3(2) , 91-105.

\section{Introduction}

Financial inclusion is a method that can be used to measure how far of the role of

JDE (Journal of Developing Economies) p-ISSN: 2541-1012; e-ISSN: 2528-2018 DOI:10.20473/jde.v3i2.10513

Open access under a Creative Commons Attribution 4.0 International

(CC-BY)

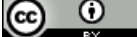


formal financial institutions in helping to improve societies welfare through financial intermediation activities. The principle of financial inclusion is basically to remove barriers to financial access so that people can receive benefits from financial services that affect the increase in income and ultimately free from poverty (Pasuhuk, 2018). In addition, according to Williams et al (2017), financial inclusion is the proper method to reduce the income gap of societies in a country.

The impact of the increasing in societies income at the individual level due to financial inclusion is ultimately expected to increase the aggregate income of the societies which has an impact on increasing economic growth, reducing poverty, and financial system stability. This is evidence from the results of research conducted by Nwanne (2015), Onaolapo (2015), Dienillah and Anggraini (2016), Williams et al (2017), Kim et al (2018), Mwaitete and George (2018), and Pasuhuk (2018) which stated that financial inclusion has a significant influence on economic growth, poverty alleviation, and financial system stability. Financial inclusion is a step to ensure that economic growth must be inclusive which can be felt by all levels of societies (Sharma et al, 2011).

However, when talking about the level of financial inclusion especially in Indonesia, based on the National Financial Literacy and Inclusion Survey (SNLIK) conducted by the Financial Services Authority (FSA) in 2016, the national financial inclusion index is known to be at 67.82 percent which increasing if compared to 2013 with 59.74 percent. The increasing of financial inclusion index was accompanied by the increasing of financial literacy index in 2013 at 21.84 percent to 29.66 percent in 2016 . The national financial inclusion index shows a fairly good increasing in numbers but unfortunately not for Islamic financial inclusion and Islamic financial literacy index.

In 2016 SNLIK was carried out by adding sharia aspects to measure how far of the understanding and the role of Islamic banking industries in supporting the welfare of the Indonesian societies. The Islamic financial inclusion index is known at 11.06 percent and the Islamic financial literacy index is at 8.11 percent. This numeral can be said to be incompatible with Indonesia's potentials in the development of the Financial Services Sector as described in the Indonesian Financial Services Sector Master Plan 2015-2019.

Based on the above facts, in this study want to know more in-depth about the forecasting of Islamic financial inclusion in Indonesia which is carried out through the activities of the Islamic Rural Banks (BPRS) operating in East Java Province in the period January 2014- May 2018 as the sample. Based on data from the FSA Islamic Banking Statistics (SPS) for the period January 2014 - May 2018 and SNLIK FSA (2016), East Java is the province with the most number of BPRS in Indonesia with the last number in May 2018 as many as 29 units and included in one of the provinces with the highest of financial inclusion index in Indonesia. In addition, according to SNLIK FSA (2016), the Islamic banking sector is the highest contributor to the Islamic financial inclusion index i.e. 9.61 percent followed by the Sharia insurance industry at 1.92 percent, pawnshop 0.71 percent, financing institutions 0.24 percent, capital market 0.01 percent, and funds retirement as many as 0.00 percent.

BPRS is a type of Islamic bank with a target of micro customers. The role of the BPRS as a microfinance institution in reaching public financial services can be said to be greater when compared to Islamic Commercial Banks. According to Mishra and Singh (2017), microfinance institutions have a vital role in increasing income and improving the living standards of the poor. BPRS is considered more capable in removing barriers in the banking industries so that it can realize financial inclusion although there are still shortcomings and challenges that must be faced (Susilo, 2015). 
Financial inclusion is something that needs to be realized for a country to ensure that development success is followed by equal income distribution in real life. Financial institutions have a vital role as a medium to bridge the distribution of income distribution through the activities of financial intermediation (Umar, 2017). Looking at the benefits of financial inclusion both at the micro and macro level, it is necessary to conduct more in-depth research on forecasting financial inclusion through the activities of BPRS in East Java until 2020. According to Alliance for Financial Inclusion (AFI) (2015), 50 percent of the world's population will be "middle class" in 2020 and those are being big potential for financial institution to expand their business. The forecasting in this study use an Autoregressive Integrated Moving Average (ARIMA) method using three of the four indicators of financial inclusion issued by Bank Indonesia in 2014, namely access, usage, and quality (Bank Indonesia, 2014).

\section{Theoretical Basis}

\section{Financial Inclusion (Principles and Objectives)}

Financial inclusion is the agenda of countries in the world because in its application can provide benefits to the economy of a country. After the crisis in 2008 , financial inclusion became a concern especially for developing countries due to the impact of the crisis felt by the bottom of pyramid (Umar, 2017). According to the World Bank (2014), more than 50 countries in the world have set targets or goals towards increasing financial inclusion. In fact, in G-20 member countries have launched a financial inclusion platform called The Global Partnership for Financial Inclusion (GPFI) in 2010 which serves as a media for discussion, policy advocacy, and coordination for G-20 member countries and countries non-G-20 member countries (GPFI, 2011).

This situation shows that financial institutions have a very large role to play in improving people's lives through financial service activities. The World Bank report (2014) explains that 2.5 billion people in the world do not have an account with formal financial institutions which should be a potential to improve their welfare through the activities of financial institutions. However, various obstacles faced by the community to be able to access formal financial services. Barriers to formal financial services faced by the community according to the World Bank (2014) are the costs, the location of financial institutions with the residence of the community, and various regulations that cannot be filled by the community, one of which is a collateral of financing.

To overcome these problems, according to the results of the G-20 Leader Summit 2010 held in Toronto, there are nine innovative principles for realizing financial inclusion. These principles are leadership, diversity, innovation, protection, empowernment, cooperation, knowledge, proportionality, and framework. These principles were created with a view to increasing understanding that the objectives of financial inclusion can be realized using appropriate approaches within a country. The objectives to be achieved from the existence of financial inclusion are inclusive economic prosperity which means that there is a decrease in poverty, income distribution and financial system stability through the creation of a financial system that can be accessed by all levels of societies (Bank Indonesia, 2014).

\section{Grameen Bank (Evidence of Successful Financial Inclusion through Microfinance Institutions)}

Grameen Bank is a microfinance institution that has the object of the poor especially women. Grameen Bank was founded by Professor in Economics, Muhammad Yunus in Bangladesh in 1983, which began with his anxiety of economics theories that are so slick, but there are still many people who get hunger in this world. On this basis, he then began his idea of empowering the community with the objects of 42 poor people around Chittagong University 
with funding needs at the time of 27 US dollars (Yunus, 2004).

According to Yunus (2004), the establishment of Grameen Bank is based on several problems faced by the banking system at the moment, one of which is its inability to accept poor customers on the grounds of creditworthy. In the mechanism, Grameen Bank does not charge collateral at all because the principle used is trust. Instead, the system used in the operation of Grameen Bank is collective credit through the formation of community groups and credit is given in sequence (Khandeker et al, 1994). In other words, the credit smoothness supervisor is a member of the community group.

Until 2012, Grameen Bank had channeled loans of 1,039 million US dollars to 23.82 million debtors or 0.89 percent of GDP and Bangladesh was considered a pioneer in empowering the poor to be able to access formal financial institutions (GPFI, 2014). In addition, according to Mainsah et al (2004), Bangladesh's poor are predicted to escape poverty by 87,000 people per month due to Grameen Bank micro-credit. Apart from the system used by Grameen Bank, it is still based on interest, but financial institutions should begin to improve by paying attention to all levels of societies, especially the poor. The fear of the inability to repay credit by the poor has been proven by Grameen Bank that of the total loans funded in 2003 i.e. 4 billion US Dollars that was paid in the amount of 3.6 billion US Dollars (Yunus, 2004).

\section{Previous Research}

This study was written based on studies related to the topics in this study that have been conducted by previous authors as follows:

Table 1: Previous Research Related to Financial Inclusion through Microfinance Institutions

\begin{tabular}{|c|c|c|c|c|c|}
\hline No. & Title & Authors & Period & Methods & Results \\
\hline 1 & $\begin{array}{l}\text { The Role of Islam- } \\
\text { ic Finance in En- } \\
\text { hancing Financial } \\
\text { Inclusion in Orga- } \\
\text { nization of Islam- } \\
\text { ic Cooperation } \\
\text { (OIC) Countries }\end{array}$ & $\begin{array}{l}\text { Mahmoud } \\
\text { Mohieldin, } \\
\text { Zamir lqbal, } \\
\text { Ahmed } \\
\text { Rostom, and } \\
\text { Xiaochen Fu }\end{array}$ & $\begin{array}{c}2010 \text { to } \\
2011\end{array}$ & $\begin{array}{l}\text { Compara- } \\
\text { tive Re- } \\
\text { search }\end{array}$ & $\begin{array}{l}\text { Islam offers a rich set of in- } \\
\text { struments and unconven- } \\
\text { tional approaches, which, if } \\
\text { implemented in true spirit, } \\
\text { can lead to reduced pover- } \\
\text { ty and inequality in Muslim } \\
\text { countries plagued by massive } \\
\text { poverty. }\end{array}$ \\
\hline
\end{tabular}

\begin{tabular}{|c|c|c|c|c|c|}
\hline 2 & $\begin{array}{l}\text { Islamic Microfi- } \\
\text { nance: Moving } \\
\text { Beyond Financial } \\
\text { Inclusion }\end{array}$ & $\begin{array}{l}\text { Abd Elrah- } \\
\text { man Elzahi } \\
\text { Saaid Ali }\end{array}$ & $\begin{array}{c}2004 \text { to } \\
2012\end{array}$ & $\begin{array}{c}\text { Descriptive } \\
\text { Analysis }\end{array}$ & $\begin{array}{l}\text { Islamic microfinance is mov- } \\
\text { ing beyond conventional } \\
\text { counterpart to provide effec- } \\
\text { tive social and financial inclu- } \\
\text { sion simultaneously. This is } \\
\text { done through Islamic social } \\
\text { tools such as Sadaqah, wafq, } \\
\text { and Zakah. }\end{array}$ \\
\hline 3 & $\begin{array}{l}\text { Model Building } \\
\text { and Forecasting } \\
\text { of Bank Credit to } \\
\text { Public and Private } \\
\text { Sector }\end{array}$ & $\begin{array}{c}\text { Ammara } \\
\text { Noreen et al }\end{array}$ & $\begin{array}{c}1983 \text { to } \\
2013\end{array}$ & ARIMA & $\begin{array}{l}\text { ARIMA model }(1,1,0) \text { is suit- } \\
\text { able for forecasting bank } \\
\text { credit to public sector and } \\
\text { forecasted value for } 2014 \\
\text { is } 4086281 \text {. ARIMA model } \\
(3,2,3) \text { is suitable for bank } \\
\text { credit to private sector and } \\
\text { forecasted value for } 2014 \text { is } \\
428322.8 \text {. }\end{array}$ \\
\hline 4 & Contribution of & Pinkan & 2007 to & OLS & The presence of banks \\
\hline
\end{tabular}




\begin{tabular}{|c|c|c|c|c|c|}
\hline No. & Title & Authors & Period & Methods & Results \\
\hline & $\begin{array}{l}\text { Financial Depth } \\
\text { and Financial Ac- } \\
\text { cess to Poverty } \\
\text { Reduction in In- } \\
\text { donesia }\end{array}$ & $\begin{array}{c}\text { Mariskania } \\
\text { Pasuhuk }\end{array}$ & 2015 & $\begin{array}{l}\text { (Ordinary } \\
\text { Least } \\
\text { Squares) }\end{array}$ & $\begin{array}{l}\text { and cooperatives is proven } \\
\text { to have statistically signifi- } \\
\text { cant and negative association } \\
\text { with poverty, confirming the } \\
\text { importance of financial insti- } \\
\text { tutions and their role in alle- } \\
\text { viating poverty. }\end{array}$ \\
\hline 5 & $\begin{array}{l}\text { Islamic Microfi- } \\
\text { nance As a Tool } \\
\text { of Financial In- } \\
\text { clusion in Bangla- } \\
\text { desh }\end{array}$ & $\begin{array}{c}\text { Md Golzare } \\
\text { Nabi et al }\end{array}$ & 2015 & $\begin{array}{c}\text { Descriptive } \\
\text { Analysis }\end{array}$ & $\begin{array}{l}\text { Islamic Microfinance program } \\
\text { may act as viable tool in pro- } \\
\text { moting financial inclusion and } \\
\text { combating poverty through } \\
\text { its inclusive and innovative } \\
\text { models based on zakat, sa- } \\
\text { daka, wafq, and commercial } \\
\text { funds to cater the demand of } \\
\text { all categories of poor. }\end{array}$ \\
\hline 6 & $\begin{array}{l}\text { Determining and } \\
\text { Forcasting Finan- } \\
\text { cial Inclusion in } \\
\text { Northern Ghana } \\
\text { Using Dicriminant } \\
\text { Analysis }\end{array}$ & $\begin{array}{l}\text { Issahaku } \\
\text { Yakubu et al }\end{array}$ & - & $\begin{array}{l}\text { Discriminant } \\
\text { Analysis }\end{array}$ & $\begin{array}{l}\text { The most significant deter- } \\
\text { minants of financial inclusion } \\
\text { in Northern Ghana are Age, } \\
\text { Cost, Capability, Literacy, Dis- } \\
\text { tance, and Employment. Over } \\
\text { all ar } 72,4 \% \text {. }\end{array}$ \\
\hline
\end{tabular}

\section{Data and Methodology}

\section{Type and Data Source}

This research was conducted using secondary data with time series data in the period January 2014 - May 2018 obtained from the Islamic Banking Statistics (SPS) of the Financial Services Authority (FSA). The data obtained from the SPS FSA is the number of BPRS in East Java, BPRS's DPK in East Java, BPRS's total financing in East Java, BPRS's total assets in East Java, and level of BPRS's NPF in East Java.

\section{Operational Definition of Research Variables}

This research was conducted with the aim to determine the forecasting value of the level of financial inclusion in East Java through microfinance institutions (BPRS) by using three of the four indicators of financial inclusion issued by Bank Indonesia in 2014 covering access, usage, and quality. Financial inclusion forecasting is done using the Autoregressive Integrated Moving Average (ARIMA).

Table 2: Definition of Research Variables

\begin{tabular}{cccc}
\hline Variable Name & $\begin{array}{c}\text { Financial Inclusion Indi- } \\
\text { cators }\end{array}$ & Symbol & Definition \\
\hline BPRS Numbers & Access & $\begin{array}{c}\text { BPRS Num- } \\
\text { bers }\end{array}$ & The number of BPRS in East Java \\
\hline Third Party Funds & Usage & DPK & The amount of BPRS third party \\
funds in East Java
\end{tabular}




\begin{tabular}{cccc}
\hline Variable Name & $\begin{array}{c}\text { Financial Inclusion Indi- } \\
\text { cators }\end{array}$ & Symbol & Definition \\
\hline $\begin{array}{c}\text { Non-Performing Financ- } \\
\text { ing }\end{array}$ & Quality & NPF & The NPF value of BPRS in East Java \\
\hline
\end{tabular}

\section{Data Analysis Technique (ARIMA Model)}

The data analysis technique used in this study is ARIMA. The ARIMA model is used to forecast financial inclusion based on three indicators of financial inclusion issued by Bank Indonesia, namely access, usage, and quality.

ARIMA is an Autoregressive Moving Average (ARMA) model with time series data integrated. The consequence of the integrated data is the data not stationary at the level but that is stationary on the first derivative or second derivative. According to Winanrno (2015), time series data that can be processed with the ARIMA model that has characteristics I(d) and if conducted differentially as many as $d$ times, it will get data $I(0)$ which becomes stationary.

The ARIMA model is also known as the Box-Jenkins method, which is a method that bases the analysis on past data and does not pay attention to other variables that are different from regression analysis in general because it is not based on the theory (Winarno, 2015). To determine the use of the best ARIMA model $(p, d, q)$, it is done through the following stages: (1) identify the model by selecting $p, d$, $q$ while looking at the value of the autocorrelation coefficient ( $A C)$ and the partial autocorrelation coefficient (PAC); (2) estimated parameters with computer programs. In this study Eviews software was used; (3) the residual diagnosis is white noise. If not, then repeat it to find the best ARIMA model; dan (4) conduct data forecasting with the selected equation.

The ARIMA model used in this study is to predict the condition of financial inclusion in Indonesia until December 2020 by using three of the four indicators issued by Bank Indonesia namely access, usage, and quality using the ARIMA model $(p, 1, q)$ as an example as follows:

1. Financial Inclusion Indicator (Access):

$$
\begin{aligned}
& \text { BRSNumbers }_{t}=\beta_{0}+\phi_{1} \text { BRSNumbers }_{t-1}+\phi_{2} \text { BRSNumbers }_{t-2}+\ldots \\
& +\phi_{p} \text { BRSNumbers }_{t-p}+\varepsilon_{t}+\theta_{1} \varepsilon_{t-1}+\theta_{2} \varepsilon_{t-2}+\ldots+\theta_{q} \varepsilon_{t-q}
\end{aligned}
$$

2. Financial Inclusion Indicator (Usage):

$$
\begin{aligned}
& D P K_{t}=\beta_{0}+\phi_{1} D P K_{t-1}+\phi_{2} D P K_{t-2}+\ldots \\
& +\phi_{p} D P K_{t-p}+\varepsilon_{t}+\theta_{1} \varepsilon_{t-1}+\theta_{2} \varepsilon_{t-2}+\ldots+\theta_{q} \varepsilon_{t-q}
\end{aligned}
$$

Total Financing $_{t}=\beta_{0}+\phi_{1}$ Total Financing ${ }_{t-1}+\phi_{2}$ Total Financing $_{t-2}+\ldots$.

$+\phi_{p}$ Total Financing $t^{-p}+\varepsilon_{t}+\theta_{1} \varepsilon_{t-1}+\theta_{2} \varepsilon_{t^{-2}}+\ldots+\theta_{q} \varepsilon_{t^{-q}}$

3. Financial Inclusion Indicator (Quality):

$$
\begin{aligned}
& \text { Total Assets }_{t}=\beta_{0}+\phi_{1} \text { Total Assets }_{t-1}+\phi_{2} \text { Total Assets }_{t-2}+\ldots . \\
& +\phi_{p} \text { Total Assets } s_{t-p}+\varepsilon_{t}+\theta_{1} \varepsilon_{t-1}+\theta_{2} \varepsilon_{t-2}+\ldots+\theta_{q} \varepsilon_{t-q} \\
& N P F_{t}=\beta_{0}+\phi_{1} N P F_{t-1}+\phi_{2} N P F_{t-2}+\ldots \\
& +\phi_{p} N P F_{t-p}+\varepsilon_{t}+\theta_{1} \varepsilon_{t-1}+\theta_{2} \varepsilon_{t-2}+\ldots+\theta_{q} \varepsilon_{t-q}
\end{aligned}
$$

Where BPRSNumberst, DPKt, Total Financingt, Total Assetst, and NPFt are the data used to 
forecast financial inclusion in East Java with the difference in orders 1 and $\varnothing, \beta$, and $\theta$ are estimated parameters.

\section{Discussion And Analysis}

\section{Descriptive Analysis}

Descriptive analysis aims to determine the characteristics of the data that will be used in this study and explain the growth of financial inclusion based on influential indicators. Historically the number of BPRS in East Java Province shows a negative trend. Figure 1 shows that the growth in the number of BPRS in the observation period starting from January 2014 to May 2018 has decreased every year. In January 2014, the number of BPRS in East Java Province was 31 BPRS and then decreased to 28 BPRS in June 2016. However, only within 6 months there were additional 1 banks in December 2016, which then lasted until May 2018 there are 29 BPRS. In Figure 1, there is a disconnected line from July to November 2015 due to the transition at Bank Indonesia where all data and information related to banking will shift to the Financial Services Authority (FSA).

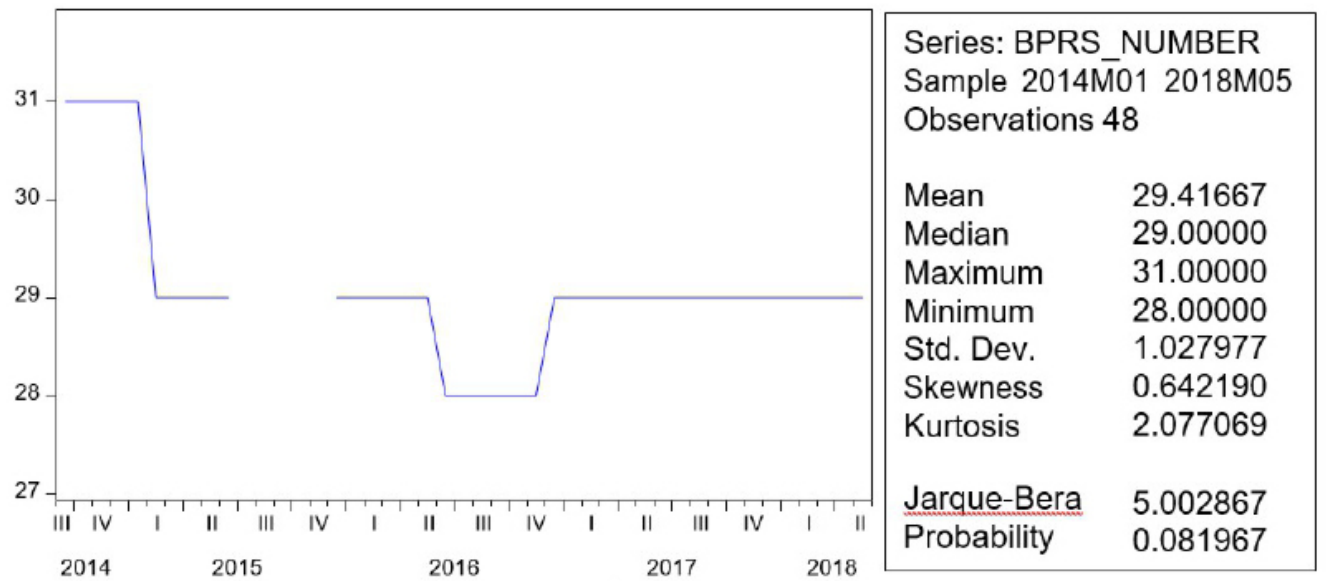

Figure 1: BPRS Numbers in East Java Province

Source: Data Processed (2018)

While the amount of third party fund (DPK), total financing, and total assets shows an increasing trend (see Figure 2). The amount of DPK in the observation period starting from January 2014 to May 2018 experienced a very drastic increasing in December 2014, then declined back to normal in January 2015. This tends to recur in 2017, which increase dramatically in December and again decreases normally. However, the amount of DPK remains in a positive trend. This shows that the level of East Java people's trust in Islamic banking has a significant increase. This will have a positive impact on maintaining financing activities and meeting bank needs, because one of the stimulus of sharia banking business activities is influenced by the large number of third party fund.

When looking at the amount of financing in Figure 2, the following is not seen a significant increase in each month, it actually decreased in December 2017 to 1,130,134 million Rupiah. This shows that the distribution of funds by the BPRS in East Java to the community there is no significant development. This means that there are still many MSME players of East Java who have not used financing from local BPRS. 


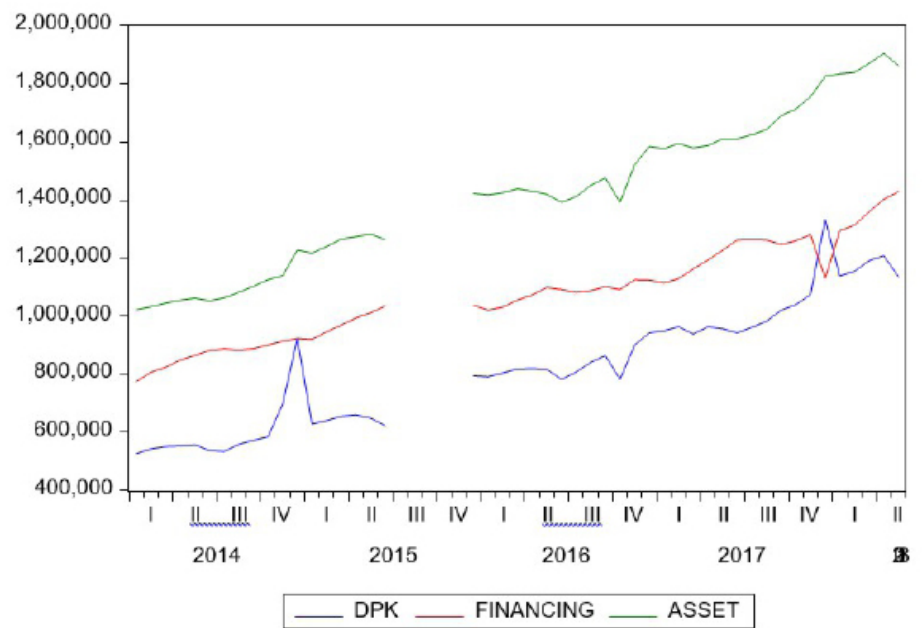

Figure 2: Growth in BPRS Total Deposits, Total Financing and Total Assets in East Java Province

Source: Data Processed (2018)

The total assets from the initial observation to May 2018 or in the period of 53 months is seen an increase from 1,022,534 million Rupiah to 1,862,899 million Rupiah. This shows that the total assets owned by BPRS in East Java have increased by almost 100 percent in less than a decade.

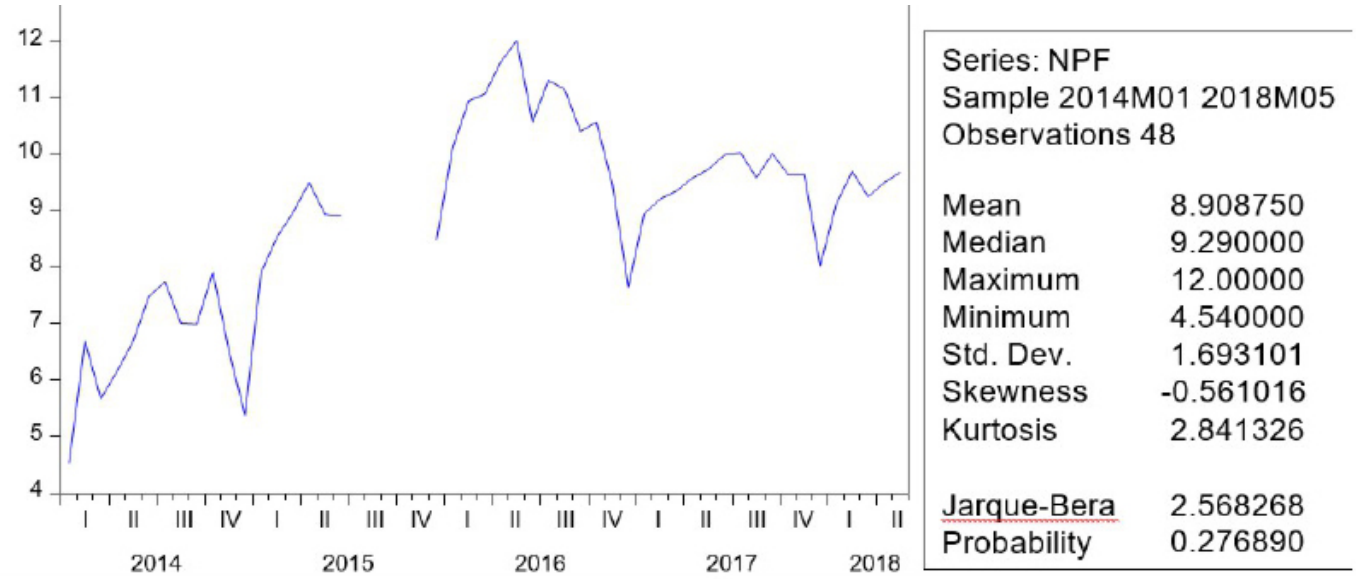

Figure 3: Growth in the Number of BPRS Non Performing Financing (NPF) in East Java

\section{Province}

Source: Data Processed (2018)

Figure 3 above explains the growth in the number of Non-Performing Financing (NPF) on BPRS in East Java Province. Historically, the graph explained that the growth of the NPF of BPRS in East Java had fluctuated from month to month. This indicates that the increase or decrease in NPF during the study period has an effect on financing distribution.

Since January 2014 to January 2016, the number of NPF growth tends to increase. This shows that the level of customer financing payments experienced bad loans (not smooth), especially in May 2016 where the NPF level increased dramatically at the highest rate of 12 percent. Furthermore, it tends to decline from September 2016 to May 2018.

However, the growth of NPF in 2014 was far better compared to today. The NPF in 2014 averaged under 6.0 percent, while the NPF currently reached 9.67 percent. This is a dangerous limit of a financial institution if the bank's NPF is above the maximum limit of 10 
percent. So, if it cannot be controlled in the long run it can cause bankruptcy.

\section{Stationary Test}

$A R, M A$ and ARMA model require that the time series data observed must have stationary properties. Time series data are said to be stationary if they meet three criteria, namely having a constant average, variant and covariance. Therefore, if the time series data observed is not stationary then a differentiation process needs to be carried out. The differentiation process is a process of looking for differences between one period of data and another period in sequence. The following are the results of the stationary test on the time series data observed in this study:

Table 3: Augmented Dicky-Fuller Test

\begin{tabular}{cccccc}
\hline No. & Variable & ADF Statistic & Critical Value(5\%) & $\begin{array}{c}\text { Mackinnon } \\
\text { Prob. }\end{array}$ & Stationary Level \\
\hline 1. & BPRS Number & -6.557439 & -1.948495 & 0.0000 & $\mathrm{I}(1)$ \\
\hline 2. & DPK & -8.953759 & -2.618579 & 0.0000 & $\mathrm{I}(1)$ \\
\hline 3. & Total Financing & -7.891498 & -1.948495 & 0.0000 & $\mathrm{I}(1)$ \\
\hline 4. & Total Asset & -5.948224 & -1.948495 & 0.0000 & $\mathrm{I}(1)$ \\
\hline 5. & NPF & -8.286241 & -1.948495 & 0.0000 & $\mathrm{I}(1)$ \\
\hline
\end{tabular}

Source: Data Processed (2018)

In table 3 it is known that the stationarity test using the Augmented Dicky-Fuller (ADF) approach does not have stationary data at the level. The results in the table show that all observations data are stationary at the first differentiation level. Stationary test on the 1st difference level is the unit root test performed on the data after the transformation follows the equation $\left(Y_{t}-\delta\right)=\alpha_{1}\left(Y_{t-1}-\delta\right)+u_{t}$ (Gujarati, 2013).

The variables aboveare stated to be stationary because it have an ADF statistical value $<5 \%$, critical value and the Mackinnon probability value is also less than $\alpha=5 \%$. Because the data used is stationary through a differencing process, so the model that will be used is ARIMA model (Widarjono, 2013).

\section{Identification of ARIMA Model and Diagnosis Test}

The next step is to do ARIMA modeling which have a function to predict the growth of financial inclusion in East Java Province. In this identification the value of $p, d$, and $q$ is determined by using the estimated Autocorrelation Function (ACF) and Partial Autocorrelation Function (PACF) in the correlogram.

\section{Table 4: Stationary Levels}

\begin{tabular}{clcc}
\hline No. & Variable & StationaryLevel & ARIMA $(p, d, q)$ \\
\hline 1. & BPRS Number & $\mathrm{I}(1)$ & 1 \\
\hline 2. & DPK & $\mathrm{I}(1)$ & 1 \\
\hline 3. & Total Financing & $\mathrm{I}(1)$ & 1 \\
\hline 4. & Total Asset & $\mathrm{I}(1)$ & 1 \\
\hline 5. & NPF & $\mathrm{I}(1)$ & 1 \\
\hline Source: Data Processed (2018) & &
\end{tabular}

From table 4 it can be seen from the component $d$ value of an ARIMA model that 
will be used in each variable is 1 . So the variables of BPRS number, DPK, total financing, total assets and NPF have the possibility of ARIMA models $(p, 1, q)$. While the $p$ and $q$ values used refer to the ARIMA standard model $(1, d, 1), \operatorname{ARIMA}(1, d, 2), \operatorname{ARIMA}(1, d, 3), \operatorname{ARIMA}(2, d, 1)$, $\operatorname{ARIMA}(2, d, 2)$ and so on.

In parameter estimation can be done through the least quadrant method or other estimation methods such as maximum likelihood (Widarjono, 2013). Based on the test results, a model that meets the Ljung-Box test is as follows:

Table 5: Hasil Uji Ljung-Box

\begin{tabular}{|c|c|c|c|c|c|}
\hline $\begin{array}{l}\text { White } \\
\text { Noise }\end{array}$ & Variable & $\begin{array}{l}\text { ARIMA } \\
(p, d, q)\end{array}$ & Probabilitas AR(p) & ProbabilitasMA(q) & Ljung-Box \\
\hline 1. & BPRS Number & $(2,1,5)$ & 0.0000 & 0.0000 & White Noise \\
\hline 2. & DPK & $(2,1,2)$ & 0.0000 & 0.0000 & White Noise \\
\hline 3. & Total Financing & $(1,1,0)$ & 0.0001 & - & White Noise \\
\hline 4. & Total Asset & $(0,1,1)$ & - & 0.0162 & White Noise \\
\hline 5. & NPF & $(3,1,3)$ & 0.0000 & 0.000 & White Noise \\
\hline
\end{tabular}

Source: Data Processed (2018)

Table 5 shows that each variable is stated as white noise. The variable of number of BPRS has the best model in ARIMA $(2,1,5)$, the amount of DPK in ARIMA $(2,1,1)$, the amount of financing in ARIMA $(1,1,0)$, the total assets in ARIMA $(0,1,1)$ and NPF in ARIMA $(3,1,3)$. All variables are stated as white noise because each variable has a probability level of less than $5 \%$.

According to Gujarati (2013), to get the best ARIMA model is by identifying the value of Schwarz-Criterion (SC), Akaike-Information Criterion (AIC), Hannah-Quinnon Criterion (HQ), Root-mean Squared Error (RMSE), Mean Absolute Percentage Error (MAPE), Mean- Absolute Error (MAE). The six indicators are selected based on the smallest value in each indicator, because they have a better predictive accuracy value in this study, the results of the Ljung-Box test only show one model that passes the white noise criteria, so it is not possible to re-test to determine the best model. So the model that has been obtained is considered the best model.

\section{The Forecasting of Financial Inclusion in East Java through Islamic Microfinance Institution}

The prediction of the BPRS number of East Java in December 2020 is 27 units. Based on the data observed from 2014, this shows that the number of BPRS branch offices in East Java has decreased in 2020. The decrease in the number of BPRS branches is due to the efficiency of banks. The point is that when the physical presence of the bank or its office network does not provide maximum contribution and has a poor performance, there will be an evaluation and corporate action, namely a merger. Thus, all BPRS in East Java are expected to provide better performance and special monitoring from the FSA regarding the development of the number of BPRS in East Java.

Furthermore, the results of the prediction of third party fund (DPK) shows that the funds raised increased from June 2018 amounting to 1,263,853 million Rupiah and in December 2020 to be 1,680,558 million Rupiah. This is also similar to the amount of financing made by BPRS East Java which consistently increases to 1,822,810 million Rupiah in December 2020. Thus, financing distribution grows along with the growth of third party fund or DPK. 


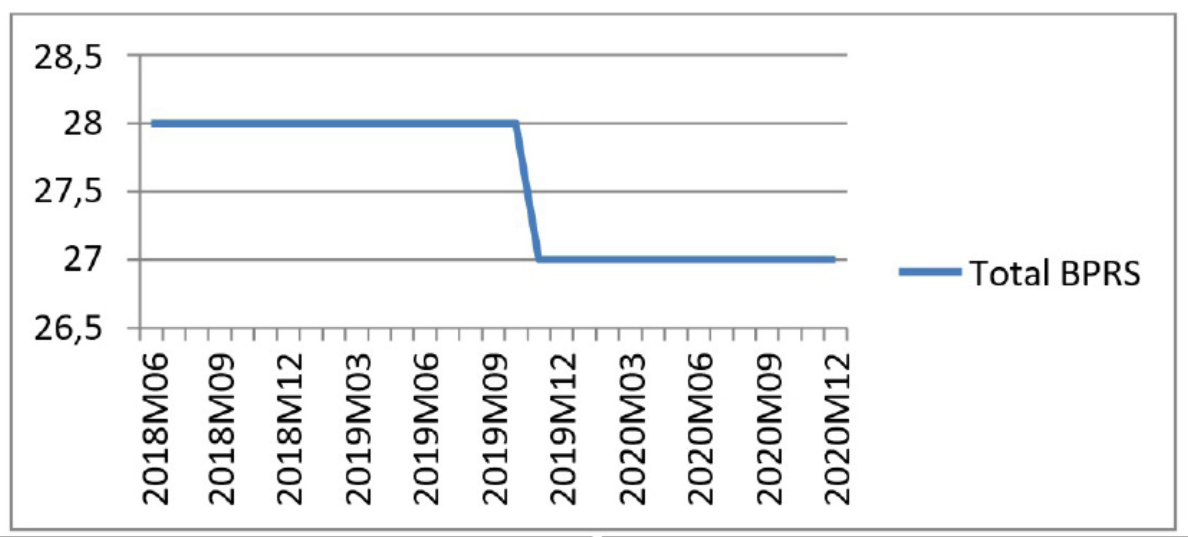

Figure 4: The Forecasting of Financial Inclusion in East Java through BPRS using Access Indicator

Source: Data Processed (2018)

Financing is the main priority of banks in allocating funds. This is because the source of bank funds comes from the community so the bank must redistribute the third party funds that have been collected to the public in the form of financing, as the function of bank is the financial intermediary. Increased funding and collection of public funds is one proof of efforts to maintain operational and financial activities in Islamic banking (Husaeni, 2017). So, from the results of these predictions it can be explained that the BPRS of East Java is able to carry out its intermediary function well. However, in connection with this, FSA is expected to be able to monitor opportunities for risks that can disrupt the stability of the financial system.

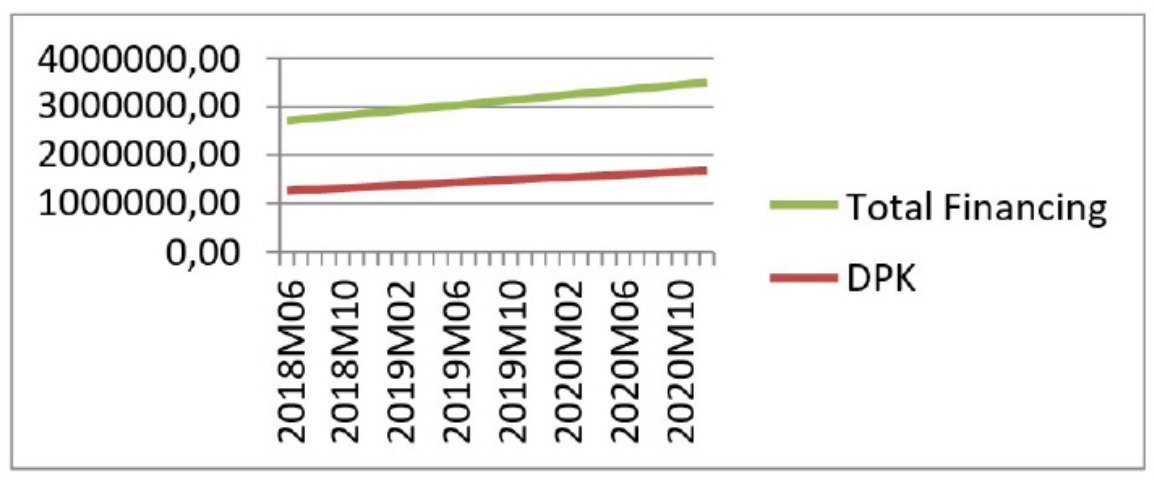

Figure 5: The Forecasting of Financial Inclusion in East Java through BPRS using Usage Indicator

Source: Data Processed (2018)

The development of Islamic banking industry in East Java is certainly related to the development of the Islamic Rural Bank. Based on the results of the forecast value shows that the total assets of BPRS in East Java have increased by 2,299,250 million Rupiah in 2020. Seeing the positive performance of the Islamic banking industry, there will be a possibility that the target of BPRS in East Java can be achieved as long as it is supported by other influential factors. Many factors can increase the growth of total assets of Islamic banking, for example the financing provided and economic growth in Indonesia. The higher the total asset value of a bank, the better the quality of the banking.

Meanwhile, the credit risk of BPRS in East Java is quite high, reflected in the NPF ratio which continues to increase by 12.48 percent in the coming December 2020 . Therefore, BPRS in East Java must strive to improve the principle of prudential banking in channeling financing. 
Considering the NPF forecast value shows that the credit risk of BPRS in East Java from 2018 to 2020 tends to increase and far from the $5 \%$ safe limit. This can be caused when there is an increase in the financing of each contract. When the growth of financing is not matched by a positive performance, it will certainly increase the risk of bad credit to Islamic banks, especially for BPRS in East Java. In addition, the increased risk of non-performing loans is also caused by the decline of the real sector growth, especially if it occurs in the mining sector, commodities and other sectors related to it. This is because the financing of Islamic banking in the mining sector and commodities is quite large.
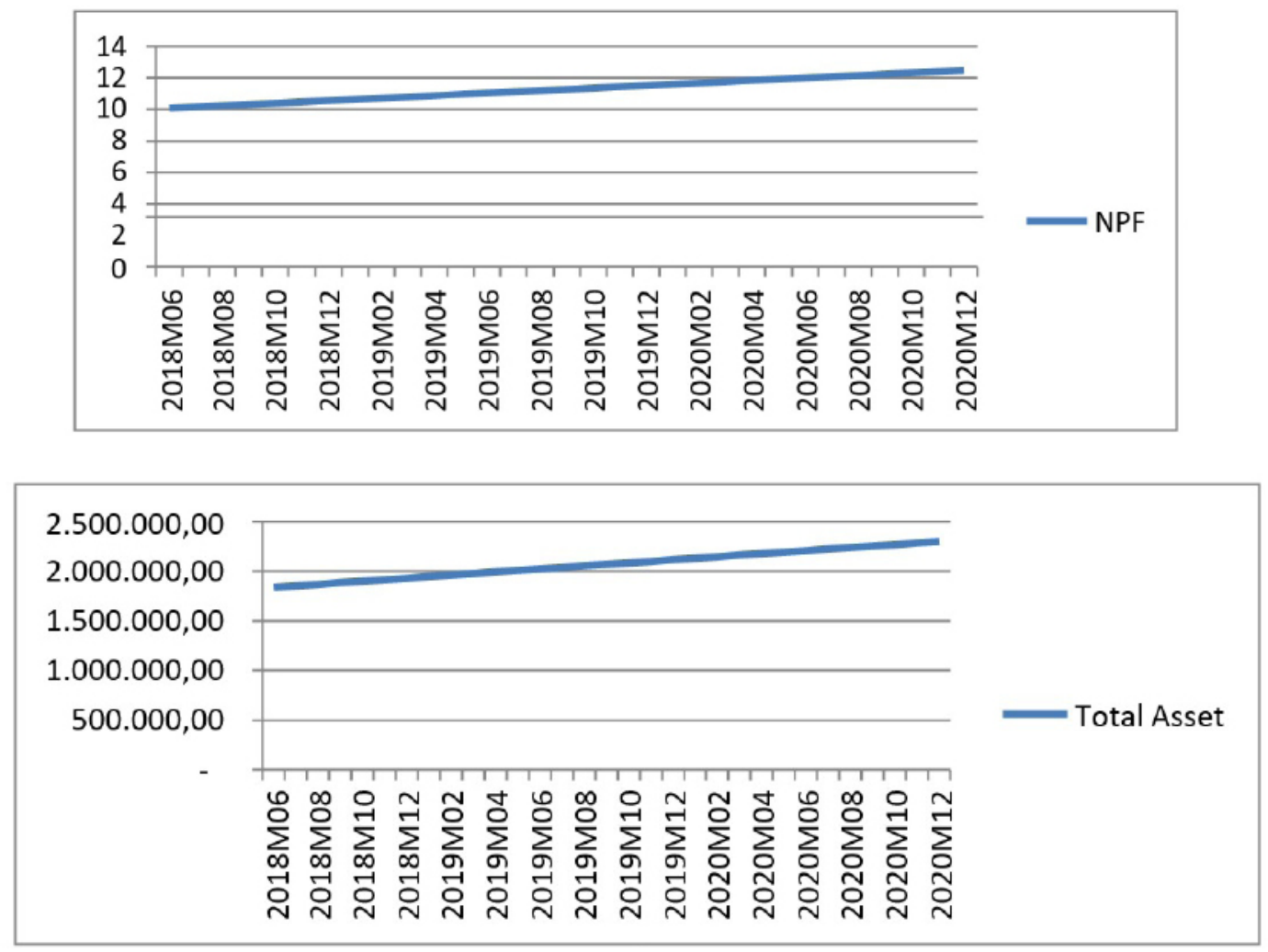

Figure 6: The Forecasting of Financial Inclusion in East Java through BPRS using Quality Indicator

Source: Data Processed (2018)

Thus, Islamic banking especially BPRS in East Java needs to improve its internal processes to be more careful in channelling financing. This includes preventing moral hazard that can encourage unhealthy financing. When BPRS in East Java are able to be optimistic and expand with a more optimal quality and supported by expectations of improved macroeconomic performance, it is possible for NPF of BPRS in East Java to decline in the coming year.

Another challenge by the Islamic banking industry, especially BPRS in East Java, is the development of information technology in the financial services industry, especially in terms of new alternative financing models offered by information technology-based companies such as financial technology. Therefore, because the challenges are getting bigger, so BPRS in East Java must have better preparation. Strong capital and good governance are important points in facing the competition. In addition, there needs to be special oversight of BPRS in East Java so that the condition of BPRS whose performance has decreased can be detected and obtain structured supervision measures. 


\section{Conclusion}

This study aims to find empirical evidence regarding the growth and prediction of the inclusive financial system in East Java Province through Islamic Microfinance Institutions. From January 2014 to May 2018 shows that the inclusive financial system which is described through the variable amount of DPK, total financing, total assets and NPF as a whole has increased. The total DPK increased to 1,135,967 million Rupiah, the amount of financing increased to $1,428,881$ million Rupiah, the total assets increased to $1,862,899$ million Rupiah and the NPF became 9.67 percent. While the number of BPRS has decreased to 29 units of BPRS.

The prediction of the ARIMA Box-Jenskin model to achieve the Alliance for Financial (AFI) goal in 2020 using the Bank Indonesia financial inclusive system indicator shows that the ARIMA model approach $(2,1,5)$ for the number of BPRS in East Java have decreased to 27 units BPRS, the ARIMA model $(2,1,2)$ for the total DPK increased to $1,680,558$ million Rupiah, the ARIMA model $(1,1,0)$ for the total financing increased to $1,882,810$ million Rupiah, the ARIMA model $(0,1,1)$ for total assets increased to 2,299,250 million Rupiah and the ARIMA model $(3,1,3)$ for NPF also increased by 12.48 percent.

Overall, this shows that Islamic rural banks in East Java have tremendous growth potential if balanced with maximum improvement and preparation. Especially in addressing the challenges faced today in the Digital Industry 4.0 era, namely regarding the development of information technology in the financial services industry, especially in terms of new alternative financing models offered by information technology-based companies such as financial technology. Thus, the development of financial inclusion in East Java will improve the quality of services in meeting customer needs.

\section{References}

Ali, A. E. E. S. (2015). Islamic Microfinance : Moving Beyond Financial Inclusion. European Scientific Journal, 11(10), 297-310.

Alliance for Financial Inclusion (AFI). (2015). The 2015 AFI Global Policy Forum Report.

Bank Indonesia. (2014). Booklet Financial Inclusion (Financial). Bank Indonesia.

Dienillah, A. A., \& Anggraeni, L. (2016). Dampak Inklusi Keuangan Terhadap Stabilitas Sistem Keuangan Di Asia. Buletin Ekonomi Moneter Dan Perbankan, 18(4), 409-430. https:// doi.org/10.21098/bemp.v18i4.574

G20 Global Partnership for Financial Inclusion. (2017). G20 Financial Inclusion Action Plan (FIAP) (Issue July). www.gpfi.org/publications/g20-financial-inclusion-action-plan-fiap-2017

Global Partnership for Financial Inclusion (GPFI). (2011). Global Partnership for Financial Inclusion Work plan 2011-2012 (Vol. 2012). http://www.gpfi.org/sites/default/files/documents/GPFI work plan-combined-200311 Aug 26.pdf

Global Partnership for Financial Inclusion (GPFI). (2014). Determining Appropriate Service Charges Based on Microfinance Institutions (MFIs) Operational Cost Data: A Case of Bangladesh (Issue January).

Gujarati, D. N. (2013). Dasar-dasar Ekonometrika (5th ed.). Jakarta: Salemba Empat. 
Husaeni, U. A. (2017). Determinan Pembiayaan Pada Bank Pembiayaan Rakyat Syariah di Indonesia. Jurnal Bisnis Dan Manajemen, 7(1), 49-62. https://doi.org/10.15408/ess. v7i1.4542

Khandkher, S., Khalily, B., \& Khan, Z. (1994). Is Grameen Bank Sustainable? (Issue February 1994).

Kim, D. W., Yu, J. S., \& Hassan, M. K. (2018). Financial inclusion and economic growth in OIC countries. Research in International Business and Finance, 43, 1-14. https://doi. org/10.1016/j.ribaf.2017.07.178

Mainsah, E., Heuer, S., Kalra, A., \& Zhang, Q. (2004). Grameen Bank: Taking Capitalism to the Poor. Journal of International Business, 1-28.

Mishra, A. K., \& Singh, C. (2017). Role of Microfinance in Financial Inclusion in Bihar-A Case Study. Journal of Business and Management, 19(9), 39-48. https://doi. org/10.9790/487X-1909083948

Mohieldin, M., Iqbal, Z., Rostom, A., \& Fu, X. (2012). The Role of Islamic Finance in Enhancing Financial Inclusion in Organization of Islamic Cooperation (OIC) Countries. Islamic Economic Studies, 20-2(2), 55-120.

Mwaitete, C. P., \& George, L. A. (2018). Financial Inclusion and Economic Growth A Regression Analysis. Imperial Journal of Interdisciplinary Research (IJIR), 4(1), 265-288.

Nabi, G., Islam, A., Bakar, R., \& Nabi, R. (2017). Islamic microfinance as a tool of financial inclusion in Bangladesh. Journal of Islamic Economics, Banking and Finance, 13(1), 24-51. https://doi.org/10.12816/0051154

Noreen, A., Asif, R., Nisar, S., \& Qayyum, N. (2017). Model Building and Forecasting of Bank Credit to Public and Private Sector. Universal Journal of Accounting and Finance, 5(4), 73-77. https://doi.org/10.13189/ujaf.2017.050401

Nwanne, T. F. I. (2015). Relationship Between Financial Inclusion and Economic Growth in Nigerian Rural Dwellers. International Journal of Small Business and Entrepreneurship Research, 3(7), 17-27.

Onaolapo, A. R. (2015). Effects of financial inclusion on the economic growth of Nigeria (19822012). International Journal of Business and Management Review, 3(8), 11-28.

Otoritas Jasa Keuangan. (2016a). Master Plan Sektor Jasa Keuangan 2015-2019: Memacu Pertumbuhan dan Menjawab Tantangan Sektor Jasa Keuangan, Kini dan Nanti.

Otoritas Jasa Keuangan. (2016b). Survei Nasional Literasi Dan Inklusi Keuangan 2016. www. ojk.go.id

Otoritas Jasa Keuangan. (2018). Statistik Perbankan Syariah Januari 2014 - Mei 2018.

Pasuhuk, P. M. (2018). Contribution of Financial Depth and Financial Access To Poverty Reduction in Indonesia. Buletin Ekonomi Moneter Dan Perbankan, 21(1), 95-122. https:// doi.org/10.21098/bemp.v21i1.892

Sharma, R., Didwania, M., \& Kumar, P. (2014). Need of Financial Inclusion for Poverty Alleviation and GDP Growth. International Journal of Multidisciplinary Research, 1(6), 83-91. https://doi.org/10.2139/ssrn.2434473 
Susilo, E. (2015). Mengentaskan Kemiskinan Dan Kebodohan Ummat Melalui Inklusi Keuangan Syariah ( Sharia Financial Inclusion ). Membangun Indonesia Berbasis Nilai-Nilai Agama, November, 1-18.

Umar, A. I. (2017). Index of Syariah Financial Inclusion in Indonesia. Buletin Ekonomi Moneter Dan Perbankan, 20(1), 99-126. https://doi.org/10.21098/bemp.v20i1.726

Widarjono, A. (2013). Ekonometrika Pengantar dan Aplikasi. Yogyakarta: Ekonosia.

Williams, H. T. (2017). Role of Financial Inclusion in Economic Growth and Poverty Reduction in A Developing Economy. Internal Journal of Research in Economics and Social Sciences (IJRESS), 7(5), 265-271.

Winarno, W. W. (2015). Analisis Ekonometrika dan Statistika dengan EViews (4th ed.). UPP STIM YKPN.

World Bank. (2014). Global Financial Development Report 2014. In International Congress on Informatics, Environment, Energy and Applications-IEEA.

Yakubu, I., Dinye, R., Buor, D., \& Iddrisu, W. A. (2017). Determining and Forecasting Financial Inclusion in Northern Ghana Using Discriminant Analysis. International Research Journal of Finance and Economics-Issue, 163(163). http://www.internationalresearchjournaloffinanceandeconomics.com

Yunus, M. (2004). Grameen Bank, Microcredit and Millennium Development Goal. Economic and Political Weekly, 39(36), 4077-4080. 